\title{
Toehold Acquisitions and the Potential Competition Doctrine
}

Although the last great tide of mergers appears to have receded, ${ }^{1}$ the Federal Trade Commission and the Antitrust Division of the Department of Justice continue to challenge conglomerate mergers ${ }^{2}$ that involve a firm of substantial size. ${ }^{3}$ Most mergers involving a "dominant" firm-an acquiring firm with annual sales of more than $\$ 200$ million or an acquired firm among the largest in a concentrated market-are still subject to close scrutiny. ${ }^{4}$

Because doctrines developed to combat earlier waves of horizontal and vertical mergers proved inadequate to prevent conglomerate acquisitions, ${ }^{5}$ the doctrine of potential competition was developed to meet

1 The number of acquisitions involving a consideration of more than $\$ 700,000$ declined to 1,237 in 1971 from 1,829 in 1968. 7 MERgers \& AcQuisitions 38 (1972).

2 The terms "merger" and "acquisition" are used interchangeably throughout this comment.

3 See, e.g., FTC v. Proctor \& Gamble Co., 386 U.S. 568 (1967); United States v. International Tel. \& Tel. Corp., 1971 Trade Cas. I 73,619 (N.D. Ill. 1971); United States v. International Tel. \& Tel. Corp., 324 F. Supp. 19 (D. Conn. 1970); United States v. CrockerAnglo Nat'l Bank, 277 F. Supp. 133 (N.D. Cal. 1967) (three-judge court); United States v. General Dynamic Corp., 258 F. Supp. 36 (S.D.N.Y. 1966); St. Joe Minerals, Dkt. 8992, 3 Trade Reg. Rep. I 20,047 (FTC 1972) (complaint); Illinois Cent. Indus., 3 Trade Reg. REP. I 20,028 (FTC 1972) (complaint); Eaton, Yale \& Towne, Inc., 3 Trade REg. REP. If 19,338 (FTG 1970) (complaint).

4 According to the guidelines issued by the Antitrust Division, the Department of Justice "will ordinarily challenge any merger between one of the most likely entrants into the market and: (i) any firm with approximately $25 \%$ or more of the market; (ii) one of the two largest firms in a market in which the shares of the two largest firms amount to approximately $50 \%$ or more; (iii) one of the four largest firms in a market in which the shares of the eight largest firms amount to approximately $75 \%$ or more, provided that the merging firm's share of the market amounts to approximately $10 \%$ or more." 1 TRADE REg. REP. f 4510, at 6887-88 (1968). Although the guidelines do not make reference to the size of the acquiring firm, Assistant Attorney General McLaren said that the Division would ordinarily challenge the acquisition of a leading firm in a concentrated industry by one of the nation's 200 largest firms. Speech before the House Ways and Means Committee, Mar. 12, 1969, 5 TrAde Reg. Rep. If 50,101 (1969); cf. Statement by Assistant Attorney General McLaren to the Senate Subcomm. on Antitrust and Monopoly, Feb. 18, 1970, 5 TRADE REg. Rep. If 50,114 (1970). The FTC's statements of "enforcement policies," promulgated for four industries, rely heavily on the absolute size of the firms involved. I TRADE REg. REP. If 4515 (1967-68).

5 The conglomerate merger does not "foreclose" commerce, for example, since the acquiring and acquired firms do not trade in each other's markets. Nor does the mere substitution of one owner for another, characteristic of congiomerate acquisitions, increase concentration in the market of the acquired firm. 
the challenge. ${ }^{6}$ As initially formulated, the doctrine prohibited both potential market entrants and firms that had once decided to enter a market by internal expansion from entering by acquiring a firm dominant in a market; such an acquisition, it was posited, would end the possibility that the acquiring firm would be an additional competitor in the market.?

When confronted with this theory, acquiring firms regularly argued that they had not been potential entrants into the market except by acquisition because, as the acquisition itself demonstrated, they had conclusively decided ${ }^{8}$ not to enter by internal expansion. Indeed, even when this argument was not made, the government found it difficult to establish that the firm was a potential entrant by internal expansion. ${ }^{9}$

In order to avoid the problem of proof inherent in the original theory of potential competition, the FTC developed the toehold acquisition corollary: once conglomerate acquisition of a dominant firm demonstrated the acquiring firm's willingness to enter the market by acquisition, ${ }^{10}$ its failure to acquire and expand a small firm (to make

B For a summary of some of the early cases, see Markham, Merger Policy under the New Section 7: A Six Year Appraisal, 43 VA. L. REv. 489, 519 (1957); cf. FTC v. Proctor \& Gamble Co., 386 U.S. 568 (1967), aff'g 58 FTG 1203 (1966); United States v. Penn-Olin Chem. Co., 378 U.S. 158 (1964); United States v. El Paso Natural Gas Co., 376 U.S. 651 (1964).

7 See Ford Motor Co. v. United States, 405 U.S. 562 (1972).

8 See, e.g., United States v. Crocker-Anglo Nat'l Bank, 277 F. Supp. 133 (N.D. Cal. 1967) (three-judge court).

9 Both "objective" and "subjective" evidence was used. "Objective" evidence includes data about the market, the firm's past expansion, and statements made about the firm by third parties. "Subjective" proof consists of internal reports and memoranda created by the firm itself. Lately the FTC has been willing to rely upon proof almost wholly objective, see The Papercraft Corp., Dkt. 8779, 3 Trade REG. REP. ๆ 19,725 (FTC 1971), and many commentators have argued that objective proof should suffice under the Clayton Act, see, e.g., Report of the Presidential Task Force on Productivity and Compemtion, 5 TRADE REG. REP. If 50,108, at 51,136 (1969) [hereinafter cited as STICLER TASK ForcE]; Brodley, Oligopoly Power under the Sherman and Clayton Acts-From Economic Theory to Legal Policy, 19 STaN. L. REv. 285, 332, 356-59 (1967); Turner, Conglomerate Mergers and Section 7 of the Clayton Act, 78 HARv. L. REv. 1313, 1384 (1965). The FTC has not yet premised a finding that a firm has violated the law solely upon objective proof. Sterling Drug Inc., Dkt. 8797, 3 Trade REg. REP. I 19,961, at 21,981 n.27 (FTĆ 1972). Objective proof was said to be insufficient by itself in United States v. Falstaff Brewing Corp., 332 F. Supp. 970, 972 (D.R.I. 1971) (dictum), prob. juris. noted, 405 U.S. 952 (1972).

The need for either form of proof was apparently rejected in Kennecott Copper Corp., Dkt. 8765, 3 TRADE REG. ReP. I 19,619, at 21,666-67 (FTC 1971), when the FTC for the first time applied the incipiency theory to a conglomerate merger. The need for proof is dramatically weakened when only an incipient decrease in potential competition must be shown.

10 Kennecott Copper Corp., Dkt. 8765, 3 Trade Rec. ReP. 19,619, at 21,699 (FTC 1971). 
a "toehold acquisition") lessened potential competition in the market.11 Acquisition and expansion was thus considered the functional equivalent of entry by internal expansion: both created increased actual competition. ${ }^{12}$

Although the FTC developed the toehold theory in response to a problem of proof, it has begun to assume a more central place in the antitrust arsenal. The courts have held the theory authorized by the Clayton Act, ${ }^{13}$ and, in at least one recent complaint, the Antitrust Division cast the failure to make a toehold acquisition as an integral part of the substantive offense of monopolization. ${ }^{14}$

This comment first examines the content and rationale of the toehold theory. The discussion suggests that because the theory was developed to meet the perceived problem of proof that potential competition had been diminished, its exact boundaries and most of its implications have never been delineated. In particular, analysis indicates that the theory's economic justification does not provide support for the use to which it has been put. The comment then examines the propriety of the theory as a tool for enforcing the Clayton Act and concludes that, even if the theory does make economic sense, it is not warranted by section 7. Finally, the comment suggests that the major significance of the theory will be to enable defendants to claim that acquisitions of a sort heretofore held unlawful are in fact legitimate toehold acquisitions.

\section{The Toehold Aceurstrion Theory}

\section{A. The Background: The Potential Competition Doctrine}

Conglomerate acquisitions have been exceedingly difficult to challenge under the Clayton Act. Only in recent years have the courts accepted the theory that such acquisitions constitute sufficiently serious decreases in potential competition ${ }^{15}$ to be cognizable under the Act. ${ }^{16}$

11 See, e.g., The Bendix Corp., 3 Trade REg. REP. If 19,288 (FTC 1970).

12 A different justification for a similar theory was advanced in the report of THE President's Task Force on ANtitrust Policy, 115 Cong. Rec. 13890 (1969) [hereinafter cited as the NEAL. TASK FORCE]. The Task Force recommended the promulgation of relatively clear rules concerning conglomerate mergers in order to channel merger activity into more procompetitive forms and in order to provide some degree of certainty in the market for small firms.

13 United States v. Parker-Hannifin Corp., Civil No. C72-493 (N.D. Ohio, May 15, 1972).

14 See text and notes at notes 45-56 infra.

15 Conglomerate acquisitions have also been criticized as creating an opportunity for "reciprocity" and the possibility of "entrenchment," but neither theory has substantial economic support. Posner, Conglomerate Mergers and Antitrust Policy: An Introduction, in Conglomerate Mergers and Agquistrions: Opinion and Analysis, 44 St. John's L. Rev. 529 (special ed. 1970).

16 The first major case acknowledging the theory was United States v. EI Paso Natural 
The existence of potential competition may have a present effect on prices in a concentrated market in which the participants are able to limit quantity and affect price. ${ }^{17}$ If the participants recognize that prices above a certain level will attract new entrants, who will expand the supply and drive prices down, the presence of potential entrants limits the prices that the current participants charge.

A conglomerate acquisition may also diminish the potential for competition, quite independently of the perceptions of the current participants, if the acquiring firm is one that would otherwise have entered the market by internal expansion. While entry by acquisition is a mere change in ownership, which leaves the market shares of the various participants unchanged, de novo entry would have expanded supply-at least in the short run. In addition, since de novo entry would have increased the number of participants in the market, it would have made collusive action more difficult to establish and maintain.

Most analysis of potential competition has been devoted to elucidating the conditions under which the elimination of an imminent de novo entrant has an actual effect on competition. It is clear that if there are few barriers to entry, the elimination of one potential entrant will not have any effect on prices in the market, since there would still be entrants if prices were increased. ${ }^{18}$ On the other hand, if there are significant barriers to entry, there will be few likely entrants. It is difficult, however, to determine whether a particular firm is a potential entrant-a determination that is crucial if the potential competition doctrine is to be applied to the particular firm that made the acquisition. ${ }^{19}$ Even if it could be established that the potential for future entry

Gas Co., 376 U.S. 651 (1964), but its use there was quite peculiar since the merger was clearly horizontal.

17 See text and notes at notes 65-77 infra.

18 See, e.g., Beatrice Foods Co., Dkt. 8814, 3 Trade Reg. REP. I 20,121 (FTC 1972); Berger \& Peterson, Conglomerate Mergers and Criteria for Defining Potential Entrants, 15 ANTTrRust BuLL. 489, 493-95 (1970); Campbell \& Shepherd, Leading-Firm Conglomerate Mergers, 13 ANTrTrust BulL. 1361 (1968); Hammond, Conglomerate Mergers and the Antitrust Laws, 1969 UTAH L. REv. 646 (1969); Handler, The Twentieth Annual Antitrust Review-1967, THE REcoRd 669, 675 (1967).

10 There is a certain tension inherent in the doctrine here. Only high barriers to entry will activate the doctrine, FTC v. Proctor \& Gamble Co., 386 U.S. 568, 571-74 (1967), but if barriers to entry are high, any particular firm is less likely to be a meaningful potential entrant. The standard of proof of a firm's ability to enter must therefore be quite high. Proving that barriers are not insuperable for one firm, however, entails proving that other similarly situated firms could have entered, which in turn demonstrates that the actual entrant does not have the unique attributes that would make the potential competition doctrine appropriate. Justice Douglas apparently did not see this problem in Proctor \& Gamble; he stressed the ease with which the company could have entered. Id. at 580. 
had a significant impact on the market, it would still be necessary to prove both that the firm entering by acquisition had sufficient access to capital to have made internal entry feasible and that the firm would have entered internally had it not entered by acquisition.

In practice, attempts to demonstrate the firm's access to capital have led to unfortunate results. Because it is difficult to analyze an individual firm's capacity to raise capital for entry, a "deep pocket" shorthand was developed. ${ }^{20} \mathrm{~A}$ firm that had achieved a certain size in assets or sales was assumed to have been capable of entering internally; for an acquiring firm lacking a deep pocket, the possibility of internal expansion was discounted. Concentration on absolute size probably identified most firms with the ability to enter de novo, ${ }^{21}$ but there was a substantial problem of overprediction-many firms have deep pockets. Courts and agencies that concentrated on proving that the acquiring firm had the ability to enter de novo were also proving, therefore, that many similar firms had the same ability. ${ }^{22}$ If many other firms could have entered equally well, the elimination of one of them could make little difference.

Thus, it became necessary to prove not only that the acquiring firm could have entered the market, but also that it was especially likely to have done so. ${ }^{23}$ Proof of both factors was of necessity subsumed under proof that entry was "imminent," a burden almost impossible to discharge. Acquiring firms were, in almost every instance, able to demonstrate that they had rejected the possibility of internal expansion. Moreover, even when management could not show that de novo entry had been rejected, the government was unable to show with any certainty how likely entry by internal expansion would have been had the option to enter by merger not been available. ${ }^{24}$ The government tried to lighten its burden by relying on "objective" proof that a firm would have entered de novo. It pointed to similarities between the markets in which the acquiring and acquired firms operated, patterns of previous expansion, the potential for profitable entry, and many other

20 See, e.g., Kennecott Copper Corp., Dkt. 8765, 3 Trade Reg. Rep. I 19,619, at 21,667 (FTC 1971); cf. FTC enforcement policies, especially that for the grocery products manufacturing industry, I Trade Reg. ReP. If 4530 (1969).

21 Firms that could have raised the necessary capital to enter through borrowing or new stock issues were overlooked, while firms that were already overcommitted and were (or should have been) in the process of retrenching their positions were included.

22 See note 19 supra.

23 For a general review of this problem and the response of the FTC and courts, see Berger \& Peterson, supra note 18.

24 See, e.g., The Bendix Corp., 3 Trade REg. REP. If 18,898 (FTC 1969) (preliminary decision). 
factors. ${ }^{25}$ The FTC, however, has not yet dispensed entirely with requirement of some "subjective" proof, ${ }^{26}$ and some courts have stated that objective proof alone is not sufficient under Clayton Act standards. ${ }^{27}$ In addition, the government would have to establish not only that the particular firm met the criteria, but also that few others did, in order to prove that the elimination of one of them was significant. ${ }^{28}$ As long as subjective proof is required, a firm can minimize the likelihood of governmental success by creating corporate documents showing rejection of internal expansion as a realistic alternative. ${ }^{29}$

\section{B. The Toehold Acquisition Theory}

The most expedient escape from these problems was to claim that the firm had committed some act that by itself proved ability and willingness to enter the market. The FTC thought it clear that acquisition of a small firm, and subsequent expansion of that firm, resembled internal expansion in most important respects. It followed that proof of ability and willingness to expand internally was unimportant if the acquiring firm could have made a toehold acquisition..$^{80}$ And since the firm had acquired a company dominant in its market, it could be inferred that the firm had both the ability to acquire a smaller company and a willingness to acquire at least some company in the market. By means of this inferential chain, the FTG essentially dispensed with the need for subjective proof of willingness and ability to enter the market de novo; entry by acquisition of a large firm proved and ad-

25 The list provided by the Supreme Court in one case alone was prodigious. See United States v. Penn-Olin Chemical Co., 378 U.S. 158, 177 (1964).

26 See Sterling Drug Inc., Dkt. 8797, 3 Trade REG. Rep. If 19,961, at 21,981 n.27 (FTC 1972). The unprofitability of a small acquisition is apparently no bar to use of the theory. The Stanley Works, Dkt. 8760, 3 Trade REg. REP. If 19,646, at 21,694 (FTC 1971).

27 United States v. Falstaff Brewing Corp., 332 F. Supp. 970, 972 (D.R.I. 1971), prob. juris. noted, 405 U.S. 952 (1972).

28 Firms meeting the criteria in one industry might meet them in several; it is obvious, however, that not all markets could be entered simultaneously. This overprediction of entry raises the clear possibility that acts will be forbidden even though they have no effect whatever on competition, and in spite of the fact that there must be some probability of actual, anticompetitive effect to make out a violation of the Clayton Act. Brown Shoe Co. v. United States, 370 U.S. 294, 319 (1962).

29 Cf. United States v. International Tel. \& Tel. Corp., 324 F. Supp. 19 (D. Conn. 1970) (successful defense to charge of reciprocity among parent and subsidiaries).

30 See Kennecott Copper Corp., Dkt. 8765, 3 Trade Reg. Rep. 1 19,619, at 21,669 (FTC 1971):

[W] believe the examiner erred in his insistence that a finding of illegality depends on Kennecott being a potential entrant by internal expansion. The form of entry is clearly not a determinative factor. Respondent admits that it was a potential entrant by acquisition. While it does not concede that it would have entered by way of a small acquisition, the toehold principle nevertheless applies. With 68 producers in the industry in 1967, there obviously were smaller firms than Peabody which could have been considered as viable acquisition candidates. 
mitted ability and willingness to enter by acquisition of a small firm, entry that would have been akin to entering by internal expansion.

The FTG has thus developed a doctrine that compares different methods of entering the market. If a firm selects a means of entry that results in less competition than some alternative means, the entry is deemed to decrease potential competition. The FTG first set forth the theory in dicta in Beatrice Foods Co.:

The competitive effects are more difficult to predict when a very small factor in the market is acquired by a substantial potential competitor. The merger may increase competition in the market by injecting a substantial firm, one capable of challenging the dominant firms in the market, in place of a firm too small to be a significant competitive factor .... The competitive effects are likely to be most serious when the merger is between one of the dominant firms in a concentrated market and a substantial potential competitor. In such a case . . . one dominant firm has simply been replaced by another and substantial potential competition is eliminated. ${ }^{31}$

The theory was first applied in The Bendix Corp. ${ }^{32}$ Bendix had acquired Fram, the dominant manufacturer of automotive filters sold as replacement parts; Bendix itself had divisions supplying other automotive replacement parts. The hearing examiner was convinced, on the basis of the evidence, that Bendix would have entered the market only through acquisition. Since Bendix could not be classified as a potential competitor under then-current doctrines, he dismissed the FTC's complaint. The Commission reversed the decision, and ordered Bendix to divest itself of Fram, because adverse effects on competition might result from the elimination of a firm that could have entered either by internal expansion "or by a toehold acquisition."33

The toehold theory applied in the Bendix case was quite rudimentary. The FTC simply concluded that anyone who acquired a dominant firm, but who might have entered by acquiring a smaller firm, had decreased potential competition. This was not a satisfactory rationale because it failed to deal with the problem of overprediction. The potential for overprediction was decreased when the theory was next applied, in Kennecott Copper Corp., ${ }^{34}$ since the FTG emphasized that Kennecott had determined to acquire at least one company in the

31 [1965-67 Transfer Binder] Trade REg. ReP. I 17,244, at 22,332 (FTC 1965).

323 Trade Reg. ReP. I 19,288 (FTG 1970), rev'g 3 Trade Reg. ReP. I 18,896 (FTC 1969).

$33 I d$. at 21,445 .

34 Dkt. 8765, 3 Trade Reg. Rcr. If 19,619 (FTC 1970). 
(coal) market. As in Bendix, the hearing examiner had dismissed the complaint for lack of proof that the respondent was a potential de novo entrant into the market. The Commission again found that the decision could not turn on that point, since Kennecott, "with its huge financial resources ... could have expanded the operations of a small company to attain ... sales" 35 sufficient to make a formerly small firm into a major market force.

The third FTC case applying the toehold theory was also decided without proof that the firm was in fact a potential entrant. In The Stanley Works, ${ }^{36}$ Stanley had acquired Amerock, the leading domestic producer of cabinet hardware. Although it had apparently decided to enter the market, Stanley contended, and the hearing examiner agreed, that it had rejected both internal expansion and smaller acquisitions as unprofitable. The FTC, however, held that the evidence that the smaller acquisitions had been rejected was irrelevant.

Since the purpose of requiring a toehold acquisition is to increase competition and prevent prices from being maintained at an artificial level, the fact that the toehold acquisition would be less profitableor even unprofitable - cannot be accepted as a defense to a charge of decreasing potential competition. ${ }^{37}$ It is inevitable that the toehold entry will be less profitable than acquisition of a dominant firm. Acquisition of a dominant firm will allow the acquiring firm to participate in high profits generated by a restriction of production; if the acquired dominant firm is expanded, short-term profits will fall, but the concentration in the market, and hence the potential for long-term profits, will increase. The toehold entry, however, produces no such potential for profit. The expansion of a small firm may be costly and even unprofitable in the short run; the quantity of goods produced will be larger and prices will fall; the concentration in the industry will decrease. The toehold acquisition is preferred in order to produce lower prices and a decrease in concentration. The consequential lower profitability cannot, therefore, be interposed as a defense. ${ }^{38}$

$35 I d$. at 21,670 .

36 Dkt. 8760, 3 Trade Reg. Rep. I 19,646 (FTC 1971), aff'g 3 Trade Reg. ReP. I 19,007 (FTC 1970).

37 Once unprofitability has been rejected as a defense, great care must be exercised to prevent unrealistic expansion of the number of potential competitors by acquisition. The existence of barriers to entry and unique potential competitors are still necessary before an entry by acquisition can be anticompetitive. See text and notes at notes 57-69 infra.

38 If a small acquisition would be unprofitable in the long run, no firm will intentionally enter via toehold acquisition. This, however, does not mean that the firm should be allowed to enter by acquiring a dominant participant. The firm might exercise a restraining influence by remaining on the edge of the market, ready to enter should market 
The response of the courts to this theory has been sparse and inconsistent. The Bendix decision was reversed because of a violation of the Administrative Procedure Act; ${ }^{39}$ by inventing the theory at the last moment the FTC was held to have deprived Bendix of proper notice of the charges against it. The Second Circuit recast Stanley ${ }^{40}$ as a horizontal merger case in order to avoid reversal on the same ground.41 The FTC was upheld on appeal in Kennecott, ${ }^{42}$ but the court merely ratified the result without discussing the theory.

The toehold theory has arisen in several proceedings brought by the Department of Justice. ${ }^{43}$ In United States v. Falstaff Breiving Corp..$^{44}$ a national brewery had entered the New England market by acquiring the largest local brewery. The district court refused to find that the acquisition reduced potential competition, rejecting the government's eleventh-hour claim that Falstaff could have acquired a smaller producer because, according to the court, the Falstaff management had "concluded that none of said alternatives would have effected'a reasonable probability of a profitable entry."45 The court thus rejected the standard objective proof tendered by the government and relied instead on indicia of management intent and profitability. If, however, the standard of what is best for the firm becomes the test by which toehold entries are to be judged, one of the primary purposes of the antitrust laws-to prevent firms from taking actions profitable to. themselves but costly to the public - will be thwarted. In addition, even when the toehold entry would be profitable, the firm could establish an effective defense by having top management reject it as inferior to some other course.

- A result similar to that in Falstaff was reached by a slightly different route in United States v. Atlantic. Richfield Co., ${ }^{46}$ in which the Antitrust Division had sought a preliminary injunction prohibiting . At-

conditions change and internal entry or toehold acquisition become profitable-whether because of a change in demand or costs or an attempt by the current participants to restrict supply artificially.

-39 Bendix Corp. v. FTC, 450 F.2d-534; 1971 Trade- Cas. I 73,724 (6th Cir. 1971).

40 The Stanley Works v. FTC, 469 F.2d 498, 1972 Trade Cas. If 74,207 (2d Cir. 1972).

41 Although the FTC rested its decision squarely on the toehold theory, the court found itself unable to support the toehold theory because of the Administrative Procedure Act violation, and proceeded to find against Stanley on a horizontal theory that, similarly; had not been litigated before the Commission.

42 Kennecott Copper. Corp. v. FTC, 467 F.2d 67, 79 n.8, 1972 Trade Cas. If 74,157 (10th Cir. 1972).

43 In addition to the cases discussed in the text, see United States v. Parker-Fannifin Corp., Civil No. C72-493 (N.D. Ohio, May 15, 1972).

44332 F. Supp. 970 (D.R.I. 1971), prob. juris. noted, 405 U.S. 952 (1972).

45. Id. at 972 .

46 . 297 F. Supp. 1061 (S.D.N.Y.'1969), aff'd, 401 -U.S. 986 (1971). 
lantic's acquisition of Sinclair. Sinclair was a major, although by no means dominant, participant in geographical markets in which Atlantic conducted no operations whatever.47 The government contended that Atlantic should have entered those markets by internal expansion or by smaller acquisitions if it wanted to enter them at all. The court rejected the contention summarily, finding that the government had failed to demonstrate that there were any smaller firms available or that, if there were, Atlantic would seriously have considered acquiring them. ${ }^{48}$ Since the government was unable to point to alternative acquisitions, it could not demonstrate that acquisition of the smaller firm would have had any significantly different effect on the market. The government's burden was increased by the fact that Sinclair did not occupy a dominant position. The court correctly suspected that very little competitive benefit could be achieved by forcing Atlantic to acquire a slightly smaller firm. ${ }^{49}$ The court's decision is a first step, therefore, toward a more precise statement of the theory: the acquired firm must have some minimum amount of market power before the theory can make sense.

The remaining Justice Department case in which the theory appeared is United States v. Wilson Sporting Goods Co.50 Wilson, the largest sporting goods firm in the country, proposed to acquire the manufacturer of approximately one-third of all gymnastic equipment made in the United States. The second largest competitor had 12 percent of the market, and no other firm had as much as 10 percent. Thus, the dominance of the acquired firm and the probable availability of smaller firms-factors absent in the Atlantic case-were demonstrated in Wilson, and the court enjoined the merger. It found that "virtually anything Wilson could do would be more pro-competitive than the path

47 Sinclair and Atlantic Richfeld were direct competitors in other sections of the country,

$48 \mathrm{It}$ is difficult to determine whether this decision reflects hostility toward the toehold theory or merely the government's failure to meet the rigorous burden of proof required for a preliminary injunction. The -United States did not, for example, offer a list of alternative and likely acquisitions, as the FTC has done in each of its toehold theory cases. There also seems to be an implied requirement in the decision that the government prove that Atlantic was willing to make a smaller acquisition. If this requirement could be administered so as to disregard paper disclaimers of intent to acquire, it could serve to prevent the universe of "potential competitors" from expanding indefinitely through serial inferences.

49 The court might also have noted that the government did not attempt to show that Atlantic had any unique attributes as a potential competitor.

50288 F. Supp. 543 (N.D. Ill. 1968). This was also a request for preliminary injunctive relief, but the court made little reference to the higher standard of proof that had to bc. met. 
it has chosen:"61 The court mentioned both making a toehold entry and remaining a bystander to the market as acceptable alternatives.

The Wilson court appears to have accepted the toehold theory in virtually the same form as it is used by the FTC: a large firm's acquisition of a dominant firm in a concentrated market violates the Clayton Act because the acquiring firm could have entered the market in a more procompetitive way by making a toehold acquisition.

\section{Advantages of the Toehold Theory}

The toehold theory has achieved its major victory by avoiding many of the evidentiary problems ${ }^{52}$ that had plagued the FTG in the prosecution of potential competition cases. ${ }^{53}$ It obviates the need to demonstrate that the acquiring firm would or could have entered by internal expansion. But the theory has other advantages that should not be overlooked. Although its operation is not absolutely clear, the theory does make it easier for large concerns to predict that certain of their contemplated acquisitions will not be challenged. Firms that come within the emergent definition of a "toehold" may be acquired without fear that the transaction will later be reversed. Increased certainty will reduce transaction costs in consummating mergers and improve the market for small firms, raising the rewards for entrepreneurship accordingly. ${ }^{54}$

More importantly, the theory channels merger activity into more procompetitive forms. ${ }^{55}$ Firms desiring to enter a market are more likely to make a procompetitive entry resembling internal expansion than to acquire a dominant firm and leave the market structure unchanged. This channeling of merger activity may in the long run lead to

51 Id. at 563 .

52 But see The Stanley Works v. FTC, 469 F.2d 498, 501-02, n.8, 1972 Trade Cas. If 74,207 (2d Cir. 1972) (dictum): "The Commission did not point to any evidence indicating that Stanley exercised a 'disciplining effect' on the market, nor did it illustrate how Stanley's acquisition of Amerock would contribute to raising barriers to entry . . .." The dissent would have required not only the objective proof to which the majority referred, but also proof that the company had "irrevocably abandoned" alternative avenues of entry.

53 See generally Turner, supra note 9; 39 Fordham L. Rev. 515 (1971); 24 VAND. L. Rev. 121 (1970). The toehold theory has been uncritically accepted by enforcement officials. See Jones \& Heiden, Conglomerates: The Need for Rational Policy Making, in Conglomerate Mergers and AcQuistitons: Opinion and ANALysis, 44 St. JohN's L. Rev. 245, 255-57 (special ed. 1970); Address by Thomas E. Kauper, Assistant Attorney General, 11th Annual Corporate Counsel Institute, Northwestern University, Oct. 4, 1972, 5 TRADE REg. REP. If 50,149 , at 55,253 .

54 Stigler TASK Force, supra note 9; cf. C. KAYSEN \& D. TURner, ANTIrrust Policy: AN Economic AND LEgat. ANALYSIs 127-28 (1959); Turner, supra note 9, at 1316-18.

55 See note 12 supra. 
decentralization of certain markets and a consequent increase in competition. $^{58}$

\section{ECONOMIG Aspects}

The toehold theory was developed totally without reference to the economic precepts underlying the antitrust laws. The theory will serve little purpose, however, unless its strictures are directed against economically meaningful targets. When the law begins to proscribe effcient or harmless forms of organization, it is imperative to reassess the law rather than to ignore the economics. Since the toehold theory depends upon the validity of the potential competition doctrine, it is important to understand the exact conditions under which entry into the market can decrease potential competition.

\section{A. Basic Economics of Potential Competition ${ }^{57}$}

Potential competition can be meaningful only in a market in which actual competition has been suppressed by some means. If competitive forces are working properly, no number of actual or potential entrants will increase output or decrease prices. The ability to affect prices is usually present only when there is some degree of market concentration. The more concentrated the market, the more likely it is that an attempt to maintain prices will be successful. ${ }^{58}$ With fewer significant firms it is less costly to initiate and police a mechanism for curtailing output, whether overt (specific agreement) or implicit (price leadership). Similarly, the more concentrated the market, the less likely it is that a small nonparticipating firm can expeditiously expand its production and dissipate the benefits of the cartel.

When concentration in an industry is great enough for participating firms to restrict supply, the market is referred to as an "oligopoly." Although there is a good deal of disagreement as to the conditions

58 Cf. Campbell \& Shepherd, supra note 18 (rule to prevent the "entrenchment" of large firms).

57 This discussion draws heavily on the work of those who have advocated extensive use of the doctrine. See, e.g., J. BaIN, Barruers to New Competrtion (1956); Turner, supra note 9. Like their work, this discussion assumes that the circumstances described do occur in the real world. But see G. STIGLER, ThE ORGANIZATION OF INDUSTRY 19-22 (1968).

58 See J. Bain, supra note 57, at 182; Business Concentration and Price Policy (National Bureau of Economic Research ed. 1955); studies collected in Brozen, The Antitrust Task Force Deconcentration Recommendation, 13 J.L. \& EcoN. 279, 280 n.5 (1970). But see J. MCGeE, IN Defense of Industrial Concentration (1971); Brozen, Bain's Concentration and Rates of Return Revisited, 14 J.L. \& EcoN. 351 (1971); Gort \& Hogarty, New Evidence on Mergers, 13 J.L. \& Econ. 167 (1970). 
required for oligopolistic power, ${ }^{59}$ it is safe to assume that it is present when the four largest firms account for 70 percent of all sales.

Even when an oligopoly exists, the participants in the market will not be able to raise their prices without attracting new entrants unless entry is somehow impeded. Two types of impediments may arise: true barriers to entry, and the time lag required to implement a decision to enter the market. A.true barrier to entry is a cost not incurred by firms already in the market that a new firm must bear in order to enter that market. It may require time to enter even in the absence of true barriers to entry, but the lag between decision and actual entry probably increases with the significance of whatever true barriers there may:be."

Barriers to entry have always been recognized as the essential force keeping potential competitors from entering the market. ${ }^{60}$ A true barrier to entry exists only when long-term costs to prospective entrants are higher than the costs of those firms already in the market. ${ }^{61} \mathrm{Al}-$ though some economists have questioned the existence of any meaningful barriers to entry in most markets, ${ }^{62}$ their existence is critical to the potential competition doctrine. Without them, any price oligopolists

69 The Department of Justice Merger Guidelines, 1 TRADE REg. REP. I 4510, at 6884, indicate that a market is "highly concentrated" when the four largest firms account for 75 percent of market sales, but merger activity is restrained in less concentrated markets as well. Cf. C. KAYSEN \& D. TURNER, supra note 54, at 72 ("structural oligopoly" is an industry in which eight or fewer firms supply 50 percent of the market; three other levels of concentration are defined); J. BaIN, INDUSTrial Organization 131 (2d ed. 1968) (four -firm concentration ratio of $\mathbf{5 0}$ percent represents high-moderate concentration); STIGLER-TASK FORCE, supra note 9 (fewer than five to ten effective rivals will stifle competition).

60 See FTC v. Proctor \& Gamble Co., 386 U.S. 568 (1967); J. Barn, supra note 59, at 280-84; cf. Berger \& Peterson, supra note 18, at 493.

61 Bain classifies the various barriers into absolute cost advantages, such as ownership of a resource necessary for production, product differentiation advantages, and economies of scale. These barriers include both true cost differentials and the general "hindrances" to entry, which new entrants can meet at the same cost as did the current participants. J. BaIN, sitpra note 57, at 12. Scitovsky lists product differentiation, in the form of imperfections in the market for information, economies of scale, and differential access to capital as barriers to entry. T. ScrTovsKy, WeLFARE AND CoMpeTrmion 331-37 (1951). Stigler woúld call barriers to entry only those conditions, such as differences in entrepreneurial ability; that confer'a long-run cost advantage on established firms because other hindrances, such as product differentiation and economies of scale, increase the capital cost of entry 'but provide no other advantage to them. G. STIGLER, supra note 57, at 69-70.

62. The STICler TASK Force, supra note 9, recommended that no action be taken against conglomerate. acquisitions because there is insufficient evidence that would-be entrants into many markets face such barriers. Bain notes that " 'absolute-cost' advantages of established firms, aside possibly from. those connected with large capital requirements, do not appear (from the industries sampled) to be a frequent source of barriers to entry." $J$. BaIN, supra note 57, at 282. 
may set above the free market price will attract entry and restore more competitive behavior.

The existence of barriers to entry does not by itself establish the case for potential competition. In addition, some potential competitors must be faced with lower barriers or time lags than others, and there will be a meaningful loss of restraint on the oligopoly only if the firms with lower barriers cease to be potential competitors. If there are many potential competitors, all impeded to the same degree, the removal of one of them cannot be important, since the continued presence of the remaining firms will discipline the market to the same extent. The removed firm must have had, then, some unique qualities for its potential competition to have been effective. ${ }^{.3}$

Finally, the potential competition itself must be meaningful. Even if the participants in the market have the ability to affect prices, there are barriers to entry, and some firms possess a unique ability to enter, the potential competition will not influence prices if the current participants can maximize the present value of their profits by charging a monopoly price rather than a lower price designed to forestall entry. This may occur in two circumstances. First, the monopoly price may be less than the price needed to attract new entry. Barriers to entry may be so high that no one will enter even with the prospect of reaping monopoly profits. ${ }^{64}$ Second, it may be rational for the market participants to raise prices above the forestalling price even though to do so will attract entry. ${ }^{65}$ The present value of the short-run monopoly profits, added to the competitive return after new entry, may exceed the present value of the returns from charging the forestalling price for an indefinite period. The more time that must elapse between a potential competitor's decision to enter and its actual entry, the more likely it is that this strategy will be adopted. If it is adopted, only the potential competition of the potential entrant that faces the shortest time lag is meaningful; as the first new entrant, it will restrict the time for which the monopoly price may be charged.

If all of the conditions set forth above are satisfied, and the existence

63 It would be irrelevant that the entrant did not possess any unique advantages over the other potential competitors only if entry by the new firm itself increased the barriers faced by a second firm. This is quite unlikely ever to occur. But see FTC v. Proctor \& Gamble Co., 286 U.S. 568 (1967).

64 As economies of scale increase, the forestalling price is more likely to -approach or exceed the limit price. The new entrant, in order to capture a share of the market large enough to enable it to operate at an efficient size, will have to sell at a price lower than that necessary to attract some smaller share. It will, therefore, require a larger "cushion" between the maintained price and the competitive price before it will risk entry.

65 See Stigler, The Dominant Firm and the Inverted Umbrella, 8 J.L. \& EcoN. 167 (1965). 
of a potential competitor succeeds in enforcing a price lower than that which would otherwise be charged, elimination of that competitor may have an anticompetitive effect. It will have an anticompetitive effect if the firm is either about to enter the market (an imminent entrant) or has been recognized as a potential entrant that will enter if the price is raised above the forestalling price (a bystander). The recognition factor is important in bystander situations since the participants in the market cannot conform their behavior to an unrecognized threat of entry. Although many oligopolists are aware that at some price someone will enter, such a general realization seems more likely when there is a large group of potential entrants confronted with similar barriers to entry than it is where one entrant (or a small group of entrants) is uniquely qualified to enter. If a unique firm is not recognized as more likely than the others to enter, the price will be raised above the level at which the firm will enter and its entry will not be forestalled. In most cases involving an undifferentiated group of potential entrants, however, none will have unique attributes facilitating entry.

It should be noted that the doctrine of potential competition assumes that the entry of a new firm will return the price to a competitive level. ${ }^{66}$ This assumption is usually unfounded. When a few firms jointly control a significant share of the market, they are able to agree among themselves to curtail supply and to increase prices. The addition of another significant competitor will make the creation of such an agreement more difficult-there will be more interests to compromise-and will make the agreement more costly to police. Consequently, the more participants there are in the market, the less likely it is that quantity can be curtailed. But it makes little sense to assert that the injection of a new competitor will restore the market to a fully competitive price. If three competitors have conspired to affect the market, the addition of a fourth cannot alone prevent a new, four-firm conspiracy from arising. Indeed, antitrust policy is predicated upon the notion that there can be anticompetitive conduct in any market, without regard to the number of participants.

The discussion thus far has focused on the ability of oligopolists to charge a price persistently higher than market but lower than that at which new firms will enter the market. Oligopolists may also be able temporarily to charge a price in excess of the forestalling price. A

68 If the current participants knew that a new entrant would agree to continue restricting supply, they would have little incentive to forgo current monopoly profits in order to deter such entry. Regardless of the speculations of the current participants, however, there would be no economic benefit from a new entry after which quantity is still cur. tailed, and there is, therefore, no reason to promote such entry. 
potential competitor will enter, of course, only if it expects to operate profitably at its postentry price. Due to the cost of overcoming barriers to entry, however, the minimum price from which it can profit exceeds the minimum price at which current participants can profit. Gurrent participants can, therefore, temporarily set a price above the forestalling price without attracting entry; as long as the potential entrant recognizes the temporary nature of the price, it cannot be sure that its postentry price will be sufficiently high to justify its entry. The longer the administered price remains above the forestalling price, the more likely the potential entrant is to believe that the price will not be reduced again after its entry, and thus the more likely it will be to enter. This tactic relies, however, upon a threat to do something resembling "predatory price-cutting," a threat that cannot profitably be carried out. ${ }^{67}$

Once these factors are considered, it is evident that removal of a potential competitor meaningfully affects the market only if it increases the forestalling price, and that this will happen infrequently. The price actually charged must be an effective long-term forestalling pricethat is, something lower than a monopoly price. And for its removal to increase the forestalling price, the potential competitor that is eliminated must have had unique attributes. It is doubtful whether economic and legal tools are sufficiently precise to identify those few potential entrants whose disappearance has some effect, so that other mergers may be allowed to proceed unimpeded. On balance, the high cost of obtaining enough information to distinguish the harmful from the innocuous removal of a potential competitor may justify a general rule against conglomerate acquisitions, especially since there is little reason to believe that they result in true economic efficiencies. ${ }^{68}$ On the other hand, some commentators have argued persuasively that so few real decreases in potential competition are likely to result from conglomerate mergers that the entire theory of potential competition should be discarded in determining their legality. ${ }^{69}$ In any event, the toehold theory makes little, if any, advance toward a rational rule of

67 See, e.g., McGee, Predatory Price Cutting: The Standard Oil (N.J.) Case, 1 J.L. \& Econ. 137 (1958); Yamey, Predatory Price Cutting: Notes and Comments, 15 J.L. \& EcoN. 129 (1972).

68 See, e.g., Asch, Antitrust and Efficiency: Product Extension Mergers: A Comment, 37 SoUthern Econ. J. 100 (1970); Felton, Conglomerate Mergers, Concentration and Competition, 30 AM. J. Econ. Sociol. 225 (1971); Prosper \& Smith, Conglomerate Mergers and Public Policy, 5 J. Econ. Issues 117 (1971); Staff of the FTC, Conglomerate Merger Per. formance: An Empirical Analysis of Nine Corporations, 5 TRADE REG. REP. II 50,158 (1973).

60 See, e.g., G. StIGLER, supra note 57, at 21; STIGLER TASK Force, supra note 9. 
broad applicability, as the economic consequences of its application reveal.

\section{B. Economic Consequences of the Toehold Theory}

One of the major functions of the theory, as the Neal Task Force suggested, ${ }^{70}$ will be to channel merger activity toward the acquisition of small firms already in the market. It will have a procompetitive effect; therefore, whenever the acquisition and subsequent expansion of a firm is the functional equivalent of internal entry and such internal entry would itself have been procompetitive. ${ }^{71}$

As the previous discussion showed; an entry into the market is anticompetitive, because it diminishes potential competition, whenever the forestalling price is raised as a result of the entry. An entry by toehold acquisition may, however, achieve exactly this result. Assume that there are three firms standing on the edge of the market and that abilities unique to firm $A$ enable it to enter either by expansion or by toehold acquisition whenever the price exceeds $\mathrm{X}$, while firms $B$ and $C$ cannot enter until the price exceeds $X+N$. If the other conditions required for operation of the potential competition doctrine obtain, firm $A$ effectively prevents the price from rising above $\mathrm{X}$. If it enters the market in such a way that the oligopoly is preserved, ${ }^{72}$ the price can be increased to $\mathrm{X}+\mathrm{N}$ without risk of further entry. $A$ 's entry, therefore; would be anticompetitive. The best solution is for $A$ not to enter the market at all:at least in the short run. ${ }^{73}$ The toehold theory,

70 See note 12 supra.

71 Anticompetitive internal expansion is rare; but although both procompetitive and anticompetitive internal growth lie without the scope of the Clayton-Act, it makes little sense to allow anticompetitive internal growth when it does take place in a manner sub'ject to the Clayton Act.

72 See text at note 64 supra.

73 See, e.g.s; United States v: Ford Motor Co., 405 U.S. 562, (1972), in which the decree effectively prohibited Ford from entering the spark plug market for ten years. Yet the result is not antithetical to the potential competition theory of the case, as it might at first appear to be. The spark plug market is shaped by the nature of the automobile market; mechanics tend to use replacement spark plugs of the same brand as the original equipment. Spark plug manufacturers cannot exist profitably, therefore, without a share of the original equipment market. Under these circumstances, the de novo entry of Ford into the market would probably have destroyed Autolite, and the market would have been in a position identical to that in which Ford owned Autolite. Although the Clayton "Act would have conferred no jurisdiction over Ford's de novo entry, Ford acquired AutoIite and the Court took the opportunity to lessen the rigidity of the market. By forcing Ford to remain a bystander for ten years, it gave Autolite the opportunity to establish itself as an independent power. After expiration of the waiting period, Ford can act as a bystander, restraining prices, or 'enter internally and introduce new competition. Apparently it is only Ford's enforced status as bystander, at least in the short run, that can restore competition to the spark plug market. 
however, favors $A$ 's anticompetitive entry, which, if accomplished by acquisition, could have been forbidden.

If $A$ could have entered the market by toehold acquisition without raising the forestalling price, then the requisites for application of the potential competition doctrine would not be satisfied, probably because all three firms would have faced the same (or no) barriers to entry. For the same reason, however, $A$ could have entered by acquisition of a dominant firm without affecting the forestalling (prevailing) price and without decreasing actual or potential competition. Consequently, the toehold theory may be inferior, in some bystander situations, to a policy of forcing the firm to remain a bystander, exercising its effect on prices from that position. The entry of a uniquely qualified potential competitor through a toehold acquisition may, therefore, raise the forestalling price and should not be allowed; the entry, by any method, of a firm that is not uniquely qualified is irrelevant to competition and should never be forbidden. As a result, the usefulness of the toehold theory is extremely limited.

The theory may be most justifiable when it is used to attack the removal of one of only a few firms that had been bystanders or imminent internal entrants. If, in the example above, all three firms were willing to enter at price $\mathrm{X}$, the elimination of one of them would affect the probability of future entry at $X$ and thus increase the willingness and ability of firms in the market to raise their price above $X .{ }^{74}$

If ability to enter by a toehold acquisition becomes the standard for determining the legality of entering by acquiring a dominant firm, it should be considerably more difficult to find a decrease in potential competition than if the standard is ability and willingness to enter de novo. Entry by acquisition can be accomplished by means of purely financial transactions such as a simple exchange of common stock. This ease of entry significantly increases the number of firms plausibly deemed potential entrants, since there is always a large number of companies "in the market" for firms in totally unrelated fields. If one such firm were removed as a potential entrant, the likelihood of one of the remaining firms entering would probably not be seriously diminished. ${ }^{75}$ Furthermore, the ease of entry by acquisition would

74 "Willingness to enter" means no more than the existence of a probability that a frrm will enter under given conditions. If that probability is, for example, one-half for each firm, then of three bystander firms, at least one will enter in seven of eight cases in which the price exceeds $\mathrm{X}$, but two firms will produce at least one entry in only six of eight cases.

75 The elimination of one potential entrant may even increase the chances of a second potential entrant actually entering if it would be profitable for one firm to enter de novo at a given time, but not for two to do so. The probability of either firm entering, when 
refute any claim that the actual entrant possessed "unique" qualifications. Consequently, there is no reason to believe that the removal of one potential entrant will affect the price at which further entry is forestalled; all other firms with equal access to capital may enter at a price identical to that at which the acquiring firm entered.

In sum, the toehold theory may induce anticompetitive acquisitions without offering any compensatory benefit. If the standard of illegality becomes ability to enter by toehold acquisitions rather than by internal expansion, many acquisitions of "dominant" firms will be prohibited even though there is no reason to believe that they would reduce potential competition.

It is also evident that the bystander variant of the unadorned doctrine of potential competition can conserve as much time and effort as the toehold theory, without importing the economically irrational consequences of the theory into the law. The toehold theory was developed to avoid the almost impossible burden of proving that an alleged potential entrant was willing to enter de novo if it could not enter by merger. But that showing was required only because the FTC and the courts overlooked the effect of the bystander in the potential competition doctrine. A firm that is on the edge of an oligopolistic market affects prices in that market regardless of whether it is currently willing to enter. The relevant factor is its willingness to enter at some future, higher price. The economic case is established if the removal of the firm as a bystander would increase the forestalling price-that is, if the firm has unique qualities that make it the bystander with the least barrier to entry. That fact can be shown wholly through objective proof. ${ }^{6}$

Finally, there are few, if any, acquisitions that can be prohibited under the toehold theory but not under the bystander formulation of the potential competition doctrine. ${ }^{77}$ The bystander theory is analytically much more direct, and because it asks the right questions, does not involve the possibility of sanctioning anticompetitive acquisitions. By requiring the government to ascertain precisely whether a uniquely

each is guarding against the possible actions of the other may, therefore, be less than the chance of a single firm entering when the possibility of a competing simultaneous entry has been eliminated or reduced.

76 It may be more difficult to show objectively that a firm was a "recognized" entrant, since the "recognizing" firms already in the market have an interest in the outcome of the litigation.

77 The result in Kennecott Copper Corp. v. FTC, 467 F.2d 67, 1972 Trade Cas. I 74,157 (10th Cir. 1972), for example, was reached not because Kennecott had been a potential de novo entrant, or even because it had failed to make a toehold merger, but simply because "[t] $]$ he removal of Kennecott from the edge of the market and the substitution of it within the market for Peabody, the leading producer and distributor, eliminated a substantial competitive force." $I d$. at 79. 
situated firm has been removed from the edge of the market, the bystander formulation also reduces the danger of overpredicting anticompetitive effects.

\section{Undefined Areas Remaining in the Toehold Theory}

The toehold theory decries the acquisition of dominant firms in concentrated markets, but the FTC has never specified what it means by a "dominant firm" or a "concentrated market." While these ambiguities underlie the potential competition doctrine as a whole, the toehold theory raises additional questions of its own. How small must an acquired company be to qualify as a toehold? To what extent is the government relieved of its burden of proof? Does the theory apply to all cases of potential competition, or is it confined by its logic to conglomerate acquisitions? All of these questions must be answered before the expected benefits of certainty and channeling can be realized.

\section{A. Allocation of the Burden of Proof}

Since the FTC developed the toehold theory because it was unable to prove that an acquiring firm was a potential competitor, it is not surprising to find that the theory has been used to reduce the standard of proof required of the government. No court has yet attempted to specify the extent to which the need for proof may have been diminished, but the FTC seems to hold that there is no longer a need for any proof. In each of its decisions, it has said that acquisition of a dominant firm alone establishes the ability and willingness of the acquiring firm to enter by means of some smaller acquisition..$^{78}$ If this deduction is the end of its inquiry, then the FTC has erected a per se rule against conglomerate acquisitions of firms despite the statutory requirement that each case be proven individually. ${ }^{79}$

The FTG has tried to shift the burden of persuasion to the acquiring firm. Indeed, in Bendix, the Sixth Circuit seemed to assume that the toehold theory required Bendix to refute the inference that it would have made a toehold acquisition if it could not have acquired a large firm. ${ }^{80}$ The Second Circuit, however, in affirming The Stanley Works,

78 See note 30 supra.

79 Each case must be proved by substantial evidence. Federal Trade Commission Act of 1914, 15 U.S.C. $\S 45$ (c) (1970). Per se rules may be promulgated only after there is general agreement that all incidents of a class of behavior should be unlawful under the Act; this is not the case when there are conglomerate acquisitions. See generally Bork, The Rule of Reason and the Per Se Concept: Price Fixing and Market Division, 74 YALE L.J. 775 (1965), 75 YaLE L.J. 373 (1966); Comment, The Per Se Illegality of Price FixingSans Power, Purpose or Effect, 19 U. CHr. L. REv. 837 (1952).

80 Bendix Corp. v. FTC, 450 F.2d 534, 1971 Trade Cas. If 73,724 (6th Cir. 1971). The 
made several disparaging remarks about the FTC's method of "proof" and intimated that, had the decision turned on the toehold theory, it would have reversed the agency for improperly shifting the burden of proof. ${ }^{81}$

The FTG's strategy has, in fact, been to create a presumption. By law, the FTC has the burden of going forward in its proceedings. It claims to discharge that burden, however, by proving that the merger was made and that the market conditions for triggering the potential competition doctrine existed. The presumption then arises that the acquiring firm would have entered by a toehold acquisition. In effect, the FTC has ruled that a prima facie case can be made from logical inferences drawn from the fact of the large acquisition. ${ }^{82}$ Such a procedure would probably pass muster under the Glayton Act. ${ }^{83}$

The burden of proof should be allocated in accordance with the purposes of the theory, that is, to prevent only those mergers that reduce potential competition. The entire proceeding should be designed, therefore, to identify mergers that increase the forestalling price; placing the burden of proof on the respondent is ill-adapted to that end. The discussion above of the economics of the toehold doctrine indicated that the theory produces meaningful results in only a small proportion of all cases. Although a somewhat larger proportion can be expected among litigated cases, many challenged acquisitions will not, in fact, be anticompetitive. If the respondent can refute a charge only by proving that smaller firms were unavailable, the FTC will be able to neglect inquiring into all of the important factors that determine

case was remanded to the Commission because the toehold theory was introduced first in the final decision, in violation of the Administrative Procedure Act; the violation could not have prejudiced Bendix if there were no defenses to the theory.

81 See note 52 supra. The court in Kennecott ignored the problem of proof altogether when it affirmed the decision.

82 The FTC has at times seemed uneasy with this allocation of burdens. In The Stanley Works, for example, it tried to demonstrate that the company had investigated at least two other cabinet hardware manufacturers and had chosen one of them as an alternate merger target. 3 TRADE REg. REP. I 19,646, at 21,701 (FTC 1971). In Kennecott, proof was adduced that other firms in Kennecott's position were hurriedly acquiring coal producers and reserves, and that Kennecott itself had already made one toehold acquisition. 3 TRADE REG. REP. I 19,619, at 21,668 (FTC 1971). In Bendix, the FTC examined the "whole logic of Bendix's corporate development" and concluded that entry, in some form, into the replacement filter market was inevitable. 3 TRADE REg. REP. ๆ 19,288, at 21,444 (FTC 1970). Thus, in each of the toehold theory cases, the FTC offered a standard form of "objective" proof that the firm was a potential entrant. The agency apparently remains afraid to rely upon a mere recitation of the toehold theory.

83 See United States v. Philadelphia Nat'l Bank, 374 U.S. 321 (1963) (horizontal merger producing high concentration in market presumptively unlawful); Brown Shoe Co. v. United States, 370 U.S. 294 (1962) (significant foreclosure of market through vertical integration presumptively unlawful). 
the forestalling price; instead, attention will be focused on a factor that is irrelevant to the economics of the situation. As a result of this shift in the burden of proof, a broad class of mergers, few if any of which may be anticompetitive, will have been proscribed.

In order to focus inquiry on the relevant factors, a rational allocation of the burden of proof would require the government to prove each of its allegations against the acquiring firm. Objective proof should be required to demonstrate that (1) the firm was a potential entrant (2) by an available toehold merger (3) whose entry by acquisition of a dominant firm (4) increased the probability that above-market prices could be charged. If proof of these four elements is required, however, the major advantage of the toehold theory will have been dissipated. With objective proof of this force, the government could establish that the firm was a recognized bystander or an imminent entrant whose entry decreased potential competition.

\section{B. Types of Acquisitions to Which the Theory Applies}

The potential competition doctrine is used against all forms of mergers-horizontal, vertical and conglomerate. The toehold theory has been applied only to conglomerate acquisitions, ${ }^{84}$ and an examination of its rationale leads to the conclusion that any other application would be counterproductive.

The toehold acquisition is encouraged because it resembles conglomerate expansion by internal growth. Internal vertical and horizontal growth, however, produces exactly those effects that lead to condemnation of vertical and horizontal acquisitions. Horizontal mergers are forbidden when the increase in economic concentration tends to dampen competitive forces in the market. Internal growth, such as a large firm increasing its share of the market, may produce exactly that effect, but it is not illegall.85 Similarly, vertical acquisitions

84 But see PepsiCo, Inc., Dkt. 8903, 3 Trade Reg. Rep. I 20,143, at 22,132 (FTG complaint 1972) (an apparent toehold allegation in a case predominantly vertical and horizontal). Both Kennecott and Stanley had minimal horizontal components. Thus, before Kennecott acquired Peabody it had acquired a small coal firm, and when Stanley acquired Amerock, Stanley had a small architectural hardware division. Guriously, the theory has never been applied to a "pure" conglomerate acquisition, one in which the acquiring and acquired firms have no prior relation whatever. Yet the toehold theory may be the only way in which these acquisitions can be attacked, since firms that have no relation to a market rarely expand internally into that market.

85 One possible justification for this difference in treatment is that the addition of new capacity to an industry, regardless of whether it results from new entry or the expansion of a current entrant, presumably occurs because the expanding firm is more efficient than its competitors. Policymakers might, therefore, favor a market position reached by expansion over one reached by acquisition. 
are discouraged by the FTC and the Antitrust Division because they are said to "foreclose" part of the market to independent competitors. It is assumed that a vertically integrated firm will sell to or buy from itself and that outside firms will be foreclosed from a source of supply or a market for their goods. To the extent that such foreclosure occurs at $a l l, 86$ it results equally from vertical integration accomplished through internal growth and from the product of mergers. Consequently, it would be incongruous to encourage or allow vertical expansion through a toehold merger, while simultaneously attacking other mergers leading to the same end.

\section{G. Definitions of a Toehold Acquisition}

Few of the problems of proof will be resolved, and none of the desired channelling will occur, unless it is clear to all concerned which acquisitions are toeholds and which are not. At present, however, there are few guidelines on this question. The cases do no more than identify particular acquisitions that were not toeholds, but since, with one exception, ${ }^{87}$ the firms held not to be toeholds were the leading firms in the market, the holdings are not very helpful. Dicta in Beatrice Foods Co. described a desirable acquisition as one "too small to be a significant competitive factor." 88 Bendix referred to the toehold as a "small company capable of expansion into a substantial competitive force." 89 This latter definition must include some firms that are not "too small to be ... significant," since a truly insignificant firm would lack the special knowledge and market experience necessary to make it a candidate for substantial expansion..$^{90}$

These insubstantial hints at the nature of an acceptable toehold candidate were given some substance in The Stanley Works, but the substance was at considerable variance with the theory. Having described a toehold as a "small non-dominant company,"91 the FTC went on to find that two companies whose acquisition had been considered would have been acceptable toehold acquisitions. ${ }^{92}$ They were the third and

86 No foreclosure occurs unless it is more efficient for a firm to make allocation decisions by fiat than to leave them to the market. Allen, Vertical Integration and Market Foreclosure: The Case of Cement and Concrete, 14 J.L. \& Econ. 251 (1971).

87 United States v. Atlantic Richfield Co., 297 F. Supp. 1061 (S.D.N.Y. 1969), aff'd, 401 U.S. 986 (1971).

88 [1965-67 Transfer Binder] Trade Reg. Rep. \ 17,244, at 22,332 (FTC 1965).

89 The Bendix Corp., 3 Trade Reg. Rep. If 19,288, at 21,445 (FTC 1970).

90 Kennecott referred several times to "smaller firms" without elaboration. Kennecott Copper Corp., Dkt. 8765, 3 Trade Reg. ReP. ๆ 19,619, at 21,669 (FTG 1971).

913 Trade Reg. REP. I 19,646, at 21,701 (FTC 1971).

92 Id. 
fifth largest firms in the industry, with, respectively, 8.5 percent and 3.8 percent of all sales. In an industry so concentrated that the five largest firms account for 57.5 percent of industry sales, these firms were not insignificant factors.

If these firms are available as toeholds, it is difficult to know where the line will be drawn in any particular market. Any "nondominant" firm may be a toehold if dominance is defined in terms of size relative to the largest firm in the market and not in terms of ordinal position or market share. For example, the second largest firm in a very concentrated market might be available as a toehold when the largest firm has 60 percent of the sales. ${ }^{93}$ The expansion of such a firm might significantly enhance market performance. ${ }^{94}$

Certainty requires that quantitative rules for defining a toehold be promulgated. ${ }^{95}$ The rules could conveniently be linked to a quantitative definition of a "concentrated market" by making any firm not among those on which a specified concentration ratio is based available as a toehold. For example, if a market is considered concentrated because the four largest firms account for 60 percent of sales, the fifth largest firm would be an acceptable toehold; if concentration is predicated upon an eight-firm concentration ratio, the ninth largest firm would be a toehold. ${ }^{96}$

93 But cf. St. Joe Minerals, Dkt. 8892, 3 TrAdE REG. REP. I 20,047 (FTC 1972) (complaint), in which the FTC alleged that section 7 was violated when St. Joe, a major producer of lead, acquired (and substantially enlarged) Quemetco, a leading producer of lead oxide and antimonial lead. Although Quemetco had about 7 percent of the market, the largest firm in the market had about 60 percent. The structure of the industry made sales by St. Joe to Quemetco quite unlikely, Respondent's Reply to Proposed Complaint at 16 , so the acquisition is properly classified as a product-extension conglomerate merger.

94 Any acquisition of a nondominant firm that improved market performance would be acceptable if toeholds were defined in terms of market structure. This would not be justifiable under the Clayton Act, however, since wholly procompetitive acquisitions are never illegal under the Act. Acquisitions whose effect is procompetitive in one market but anticompetitive in another, though, are judged on the anticompetitive effect alone. "If anticompetitive effects in one market could be justified by procompetitive consequences in another, the logical upshot would be that every firm in an industry could, without violating $\S 7$, embark on a series of mergers that would make it in the end as large as the industry leader." United States v. Philadelphia Nat'l Bank, 374 U.S. 321, 370 (1963). Procompetitive consequences may be considered "where two small firms in a market propose to merge in order to be able to compete more successfully with the leading firms in that market." $I d$. at 370-71.

95 NEAL TASK FORCE, supra note 12, at 13892; cf. Turner, supra note 9, at 1318-19, 1386. But cf. discussion of STIGLER TASK FORCE note 62 supra.

96 It has proved exceedingly difficult to formulate standards for assessing the effect of concentration and the minimum market share at which an individual firm acquires market power. Compare C. KAYSEN \& D. TURNER, supra note 54, at 72 with J. BAIN, supra note 59, at 14-41 and NEAL TASK FORCE, supra note 12 and Stigler, Mergers and Pre- 
This basic rule could be complemented by two de minimis rules to deal with situations in which there are a few large firms and the next largest firm is quite small. First, any firm with a market share of less than 5 percent could be presumptively acceptable as a toehold even if it is among the firms on which the concentration ratio is based. Second, a firm would be an acceptable toehold when it has a market share of less than 15 percent and the next largest firm has at least twice its share of the market. ${ }^{27}$ These rules would be arbitrary, but they are not unreasonable since they would rarely allow a merger with significant anticompetitive effects or prevent a merger with significant economies. ${ }^{98}$ The benefits of certainty, made possible by the toehold theory, cannot be realized on a case-by-case basis.

\section{The Toehold Theory under Section 7}

The purpose of the toehold theory is basically to require an acquiring firm, if it wishes to enter a market, to do so by a route that "would be more pro-competitive than the path it has chosen."99 The FTG has relied upon the legislative history of the Glayton Act to demonstrate that Congress considered small acquisitions procompetitive. In Bendix, the first toehold case, it said:

Such procompetitive mergers are not only not forbidden by Section 7 , they are positively encouraged. . . . A potential entrant may enter not only by internal expansion; he may enter the market by acquiring a failing company, or a small company in difficulty, or by making a toehold acquisition of a small member of the industry. These methods of entry, no less than internal expansion, and in some cases perhaps more than entry by internal expansion, may inject a new competitive element of vigor and strength into an otherwise stagnant market. ${ }^{100}$

It quoted the above passage in its Kennecott decision and concluded

ventative Antitrust, 104 U. PA. L. REv. 176, 182 (1955) and Department of Justice Merger Guidelines, supra note 59, at 6,884 (1968). The difficulty becomes more acute when the FTC combines the potential competition doctrine with the incipiency doctrine of Brown Shoe Co. v. United States, 370 U.S. 294, 317-18 (1962), to halt acquisitions in an "incipient oligopoly." There can be neither objective standards nor certainty in that case, and it is doubtful that a convincing argument can be made that entry in any form into such a market can be anticompetitive in the sense that the forestalling price is affected. See Kennecott Copper Co., Dkt. 8765, 3 Trade Reg. REP. $\uparrow 19,619$, at 21,666-67 (FTC 1971). o7 One can imagine cases in which this rule would not work-such as a four-firm market in which the firms held shares of 40 percent, 30 percent, 15 percent, and 15 percent-but they are rare if they exist at all.

88 Cf. Campbell \& Shepherd, supra note 18, at 1379.

99 United States v. Wilson Sporting Goods Co., 288 F. Supp. 543, 563 (N.D. Ill. 1968).

100 The Bendix Corp., 3 Trade Reg. Rep. I 19,288, at 21,446 (FTC 1970). 
that " $[t]$ he antitrust goal established at a high level of government is to discourage substantial acquisitions and to channel merger activities into directions that would increase competition."101

There is no doubt that Congress did not intend to impede acquisitions that had no anticompetitive effect. It is also safe to assume that Congress would prefer a procompetitive acquisition to one that is neutral with respect to competition. But Congress has not enacted either of these sentiments, and it hardly follows that making a competitively neutral acquisition can constitute a violation of the Clayton Act simply because a procompetitive acquisition could have been made.

The doctrine of potential competition has been criticized as too speculative to form the basis for a violation of the Clayton Act. Commentators have portrayed it as an unjustified attempt to enforce the status quo because not directed against a present diminution of competition. ${ }^{102}$ The FTC and the courts have rightly rejected this criticism $^{103}$ since the elimination of potential competition makes possible an immediate increase in the forestalling price; competition is lessened when the acquisition takes place.

The potential competition doctrine compares two actual marketsyesterday's, in which the acquiring firm was a potential competitor, and today's, in which its competition has been removed. The toehold theory, in contrast, purports to compare the real market in which a potential competitor has acquired a dominant firm and the hypothetical market that would have existed had it acquired a toehold. Instead of pointing to an action that the firm has taken to decrease competition, the government points to an action that it did not take that would have increased competition. The Clayton Act, by its terms, reaches only those actions that decrease competition, not those that fail to increase competition. ${ }^{104}$

A construction of the Act to prohibit all actions that are not reasonably procompetitive ${ }^{105}$ must deal with the anomalies it produces: a

101 Kennecott Copper Corp., 3 Trade Reg. Rep. I 19,619, at 21,669 (FTC 1971).

102 See, e.g., Rahl, Applicability of the Clayton Act to Potential Competition, 12 ABA SEction of ANTTtrust LAw 128, 142-43 (1958).

103 The rejection is implicit in the outcome of United States v. Ford Motor Co., 405 U.S. 562 (1972), and all preceding cases relying on the potential competition doctrine. See Turner, supra note 9, at 1379-80; 39 Fordisim L. Rev. 515, 520 (1971). But cf. Jones \& Heiden, supra note 53, at 256: Commissioner Jones advocates looking at "the question of lost potential competition when it takes the form of a firm acquiring a leading market position and thus being a candidate for making a foothold acquisition and expanding it in a way that helps competition." (Emphasis added).

104 The NEAL TASK FORCE, supra note 12, implicitly recognized this by propasing new legislation to deal with the situation.

105 Turner would compare the degrees of competition that would result from 
firm may lawfully acquire a failing company; it may acquire a nondominant firm; and it may withdraw from the market altogether. Each course may be considerably less procompetitive than some alternative, but none is forbidden by the Act. There must be some "probability" of anticompetitive consequences, however small, to come within the statutory prohibition. ${ }^{106}$ As a comparison of real and hypothetical market states, however, the toehold theory cannot reveal a probability that present competition will be lessened by the acquisition of a dominant firm. That would require isolating the effect of the acquisition, the impossibility of which led to formulation of the theory in the first place.

\section{Use of the Toehold Theory by Defendants: AN Ironic OUTCOME}

Although the toehold theory is unlikely to enable the government to prohibit a significant group of mergers beyond those already reachable under the bystander formulation of the potential competition doctrine, ${ }^{107}$ it may prove very useful to defendants. As long as the meaning of "toehold acquisition" remains unquantified, defendants can argue that their particular merger is within the permissible limits of a reasonable definition, and they may have a good deal of success. The language and results of the FTG's own opinions suggest four ways in which the toehold theory might be used defensively.

First, the maximum allowable market share for qualification as a toehold may be challenged as unreasonably low. In Stanley, the FTC characterized the third largest firm in the cabinet hardware market, with 8.5 percent of sales, as a toehold candidate. ${ }^{108}$ If 8.5 percent qualifies in a very concentrated industry, it would not be hard to argue that 12 percent or 15 percent firms are also toehold acquisitions, especially in less concentrated markets.

Second, defendants may attempt to recast the doctrine as one prohibiting acquisition of firms based on their ordinal market position. Viewed in this light, Stanley would legitimate acquisition of the third

allowance and disallowance of the merger and forbid the merger if to do so would be more procompetitive. Turner, supra note 9, at 1380. This interpretation is even more strained when the postallowance market and some hypothetical market are compared. But see United States v. Philadelphia Nat'l Bank, 374 U.S. 321, 365 n.42 (1963): "On the contrary, if concentration is already great, the importance of preventing even slight increases in concentration and so preserving the possibility of eventual deconcentration is correspondingly great."

106 See, e.g., Brown Shoe Co. v. United States, 370 U.S. 294 (1962).

107 See text and notes at notes 70-77 supra.

108 The Stanley Works, Dkt. 8760, 3 Trade REG. REP. I 19,646, at 21,701 (FTC 1971). 
largest firm in a concentrated market. In addition, if the third firm were considerably smaller than the second, the defendant might appeal to the FTC's concern for "strengthened competition"109 on the theory that only a relatively strong firm can quickly be built to a size at which economies make competition with the very largest firms practical. ${ }^{110}$

The third avenue available to defendants involves an extension of the toehold rationale. In Bendix, the FTC referred to weak and failing firms, in addition to toeholds, as favored candidates for acquisition. ${ }^{111}$ If toehold acquisitions are to be encouraged in order to make otherwise "weak" firms more competitive, a firm with a declining share of the market should be more likely to qualify as a toehold. The firm would presumably have been acquired in order to improve its ability to compete and, therefore, improve overall market performance. This is not to suggest that a declining market share is by itself enough to require that a firm be classified as a toehold; it is a factor, however, to which any defendant to whom it is open would point in shaping the toehold concept to fit a particular acquisition.

Finally, if the acquired firm is losing money, a variation on the "failing company" defense is possible. The failing company defense may be tendered without regard to the size of the acquired company; if the firm is truly failing, ${ }^{112}$ competition is not decreased by someone acquiring it since it would otherwise disappear altogether. Similarly, acquisition of a merely weak company by a firm capable of reinvigorating it would be of greater benefit to the market than would the acquisition of a prosperous firm of like size. ${ }^{113}$ If procompetitive effect is the touch-

109 Kennecott Copper Corp., Dkt. 8765, 3 TrAde REg. REp. If 19,619, at 21,669 (FTC 1971): "Indeed, the antitrust goal established at a high level of government is to discourage substantial acquisitions and to channel merger activities into directions that would increase competition."

110 This argument would be quite illogical. Any expansion of the output of the third largest firm would, in the short run, decrease prices but increase the four-firm concentration ratio. At some future point, the more highly concentrated market that emerges would be even more susceptible to collusive or other anticompetitive behavior.

111 The Bendix Corp., 3 Trade Reg. Rep. If 19,288, at 21,446 (FTC 1970).

112 See Citizen Publishing Co. v. United States, 394 U.S. 131 (1969) (rigorous criteria laid down for the assertion of the failing company defense). In addition, the courts must still find the injury to competition from the acquisition to be outweighed by other considerations of the public interest. A firm that is losing money rapidly, thinly capitalized, and probably facing failure in the near future may not necessarily support a failing company defense in the FTC's view. See United States Steel Corp., Dkt. 8655, 3 Trade Reg. Rep. If 20,139 (FTC 1972); cf. The Papercraft Co., Dkt. 8779, 3 Trade Reg. REP. If 19,725, at 21,780 (FTC 1971).

113 Many attempts have been made to establish a less stringent (or "weak company") defense, all without success. See, e.g., United States v. G. Heileman Brewing Co., 345 F. Supp. 117, 1972 Trade Cas. If 74,080 (E.D. Mich. 1972) (acquired company had suffered "devastating losses" and falling sales; collapse was imminent). 
stone for whether an acquisition is a toehold, the courts will face a relativity they have previously rejected: at present a firm is either "failing" or it is not, and if it is not, its weak financial status and the acquiring firm's claims that competition will be increased are irrelevant. ${ }^{114}$

The orientation of the toehold theory toward the reinvigoration of firms that cannot effectively compete requires, however, that the "weak" status of the firm be taken into consideration. The weak company defense will have been revived-this time to increase the market share that may be held by a toehold acquisition.

\section{Conclusion}

As the bounds of permissible acquisition expand, whether along the four lines suggested or others, the theory will lose whatever validity it may once have had. ${ }^{115}$ Expansion will be difficult for the FTC to thwart, not only because the possible bases for extension fit within the rationale of the theory, but also because the definition of a toehold is probably a question of law. ${ }^{116}$ The FTG can support factual determinations, such as whether an acquisition decreases competition, on substantial evidence, ${ }^{117}$ but no such shield protects its conclusions of law. With the new-found opportunity to attack the Commission on a question of law, defendants will have gained a substantial advantage that they lack in most section 7 cases.

Frank H. Easterbrook

114 This is not true in all cases. The acquisition might materially increase the market share of a dominant firm, or increase the four-firm concentration ratio, if it is horizontal. And, in almost every case in which the doctrine is applied, the outcome would have been more procompetitive had some noncompeting firm acquired the failing company. The FTC has recognized this problem and will not approve the acquisition of a failing company by a competing firm until prospects of acquisition by a noncompeting firm appear to be nil. United States Steel Corp., Dkt. 8655, 3 TRAD́E REG. If 20,139 (FTC 1972); cf. United States v. Lever Brothers Co., 216 F. Supp. 887 (S.D.N.Y. 1963) (result dubious after Philadelphia National Bank); Department of Justice Merger Guidelines § 21, supra note 59, at 6889 (1968).

115 If the toehold theory is ever applied to a horizontal or vertical acquisition, successful invocation of the theory by defendants would establish a new de minimis rule with a far higher threshold than any tolerated at present.

116 See, e.g., The Stanley Works v. FTC, 469 F.2d 498, 1972 Trade Cas. I 74,207 (2d Cir. 1972); United States Steel Corp. v. FTG, 426 F.2d 592 (6th Gir. 1970).

117 Federal Trade Commission Act of 1914, 15 U.S.C. $\$ 45$ (c). 